УДК 796.062.4

DOI https://doi.org/10.26661/2663-5925-2020-1-22

\title{
ОСНОВНІ ЕКОНОМІЧНІ РЕСУРСИ NBА В СУЧАСНИХ УМОВАХ РОЗВИТКУ
}

\author{
Хіменес Х. P. \\ кандидат наук із фізичного виховання і спорту, доцент, \\ доиент кафедри теорії спорту та фізичної культури \\ Львівський державний університет фізичної культури \\ імені Івана Боберського \\ вул. Костюшка, 11, Львів, Украӥна \\ orcid.org/0000-0002-8677-6701 \\ kh.khimenes@gmail.com \\ Пітин М. П. \\ доктор наук із фізичного виховання і спорту, \\ професор кафедри теорії спорту та фізичної культури \\ Львівський державний університет фізичної культури \\ імені Івана Боберського \\ вул. Костюшка, 11, Львів, Україна \\ orcid.org/0000-0002-3537-4745 \\ pityn7@gmail.com
}

Тищенко В. О.

доктор наук із фізичного виховання і спорту, професор кафедри теорії та методики фізичної культури і спорту

Запорізький національний університет вул. Жуковського, 66, Запоріжжя, Україна orcid.org/0000-0002-9540-9612 tyshchenko@gmail.com

Ключові слова: професійний спорт, баскетбол, ліга, джерело доходу, спонсор.
Невіддільним складником професійного спорту сьогодні $є$ оптимальна побудова бізнесу для отримання якомога більших прибутків. Однією 3 найбільш успішних у цьому плані ліг $\epsilon$ NBA, яка з року в рік нарощує свої доходи завдяки веденню ефективної спортивної діяльності та, як наслідок, укладання вигідних угод. Мета дослідження - виявити основні джерела доходів сучасної NBA та обгрунтувати їх. Матеріал $i$ методи. Результати отримано здебільшого під час аналізу наявних матеріалів в інтернет-ресурсі (офіційні сайти, матеріали публікацій). Ключові методи дослідження: аналіз та узагальнення даних, порівняння. Результати. Сучасна NBA активно працює над пошуком нових ринків реалізації свого спортивного продукту - баскетбольних змагань. Станом на 2020 рік іiі дохід становить 8,76 млрд дол і ще збільшується. Клуби ліги $є$ цінним активом. Їхня середня вартість сьогодні становить 2,12 млрд дол і також ще збільшується. Сьогодні NBA отримує значні прибутки від телебачення. Ліга підписала угоду з телеканалами ESPN та TNT, згідно з якою отримає 24 млрд дол упродовж 4 років. Вагомим джерелом доходів залишається продаж квитків на матчі (вартість коливається в широкому діапазоні - від 25 до 270 дол залежно від рівня команд). Сьогодні ліга активно співпрацює 3 компаніями, які займаються розробленням мобільних додатків. Вона має підписану трирічну угоду з Verizon на 400 млн дол. Завдяки цьому 
всі відео NBA є на мобільному відеосервісі Verizon. Також ліга відкрила доступ компаніям до форми своїх спортсменів. Сьогодні, окрім офіційного спонсора Nike, на формі баскетболістів можна розміщувати логотип компанії, з якою укладає угоду той чи інший клуб. Найбільший контракт у чемпіонів із "Golden State Warriors", яким японський гігант Rakuten платить по 20 млн на рік. NBA починає захоплювати й кіберспортивний ринок за допомогою NBA2К. Планується, що в близькому майбутньому ця віртуальна ліга приноситиме також значні доходи. Загалом NBA, отримуючи мільярдні прибутки, і сьогодні досі розширює свої фінансові можливості, активно працюючи не лише на території США, але й Китаю, Індії, Свропи, і навіть Південної Америки.

\title{
MAIN ECONOMIC RESOURCES OF THE NBA IN MODERN DEVELOPMENT CONDITIONS
}

\author{
Khimenes Kh. R. \\ Candidate of Sciences in Physical Education and Sports, Associate Professor, \\ Senior Lecturer at the Department of Theory of Sport and Physical Culture \\ Lviv State University of Physical Culture named after Ivan Boberskyj \\ Kostushko str., 11, Lviv, Ukraine \\ orcid.org/0000-0002-8677-6701 \\ kh.khimenes@gmail.com \\ Pityn M. P. \\ Doctor of Sciences in Physical Education and Sports, \\ Professor at the Department of Theory of Sport and Physical Culture \\ Lviv State University of Physical Culture named after Ivan Boberskyj \\ Kostushko str., 11, Lviv, Ukraine \\ orcid.org/0000-0002-3537-4745 \\ pityn7@gmail.com \\ Tyshchenko V. O. \\ Doctor of Sciences in Physical Education and Sports, \\ Professor at the Department of Theory and Methods of Physical Culture and Sports \\ Zaporizhzhia National University \\ Zhukovskoho str., 66, Zaporizhzhia, Ukraine \\ orcid.org/0000-1812-1112-9765 \\ tyshchenko@gmail.com
}

Key words: professional sport, basketball, league, source of income, sponsor.
An integral part of professional sport today is the optimal construction of the business to maximize profits. One of the most successful leagues in this regard is the NBA, which increases its revenues from year to year through effective sports activities and, as a result, the conclusion profitable deals. The purpose of the study: to identify the main income sources of the modern NBA and substantiate them. Material and methods. The results are obtained mostly from the analysis of available materials of Internet resource (official sites, materials of publications). Key research methods: data analysis and generalization, comparison. Results. The modern NBA is actively working to find new markets for its sports product basketball competitions. Its revenue amounted 8.76 billion dollars in 2020 and continues to grow. League clubs are a valuable asset. Their average value today is 2.12 billion dollars and continues to grow. The NBA makes significant profits from television today. The league has signed an agreement with ESPN and TNT, according to which it will receive $\$ 24$ billion dollars for 4 years. 
A significant source of income is the sale of tickets to the matches (the price varies widely - from 25 to 270 dollars, depending on the level of teams). The league also actively cooperates with companies engaged in the development of mobile applications. It has a three-year deal worth $\$ 400$ million with Verizon. As a result, all NBA videos are available on Verizon's mobile video service. The league also opened companies' access to the uniforms of their athletes. Today, in addition to the official sponsor of Nike, on basketball players' form the logo of the company with which a club enters into an agreement can be placed. The champions Golden State Warriors have the biggest contract. The Japanese giant Rakuten pays to this club 20 million dollars per year. The NBA is beginning to capture the eSports market with the help of NBA2K. It is planned that in the near future this virtual league will also bring significant income. In general, the NBA receives billions of profits today and continues to expand its financial opportunities. It is actively working not only in the United States, but also in China, India, Europe, and even South America.

Вступ. Бізнес-складник професійного спорту нині активно набуває обертів. Функціонери провідних спортивних ліг здійснюють постійний пошук актуальних економічних ресурсів, які наповнювали б фонди цих організацій [7]. Проте, що $є$ частково парадоксальним, ці організації не вважаються комерційними структурами й офіційно не мають права заробляти, водночас вони повністю контролюють фінансові потоки підконтрольних їм комерційних підструктур - професійних спортивних клубів [11].

Взірцем ведення спортивного бізнесу, зокрема, на теренах США нині вважається NBA $[1 ; 11 ; 13]$. Тут не йдеться про максимальні доходи, оскільки цей рейтинг очолює NFL. Це стосується збалансованості доходів і видатків NBA щодо інших організацій професійного спорту на теренах США та вигідної співпраці з різними бізнес-структурами. Незважаючи на окремі негативні моменти, які останніми місяцями супроводжують NBA (трагічна загибель Коббі Браянта, серйозний конфлікт із владою Китаю, деяке зниження телевізійних рейтингів, наслідки пандемії COVID-19), ліга залишається на вершинах економічних рейтингів і акумулює досить високі доходи $[4 ; 6 ; 15]$.

Щодо популярності та стрімкого розвитку цієї організації, зокрема, засвідчують деякі статистичні дані. Наприклад, за останні 30 років діяльності доходи NBA від телетрансляцій зросли в 40 разів і станом на сьогодні перевищують 1 млрд дол, іiі ігри транслюються в понад 200 країнах світу сорока мовами. NBA - найпопулярніша з усіх північно-американських професійних спортивних ліг поза межами США. Вона налічує понад 15 офісів в інших країнах світу, чим не може похвалитися жодна інша ліга [7].

Сучасний етап розвитку професійного баскетболу вимагає суттєвого оновлення інформаційного аспекту в науково-теоретичній базі щодо ключових економічних складників його існу- вання. Розуміння економічних механізмів дасть змогу глибше зрозуміти сутність спортивного складника сучасного баскетболу. А отже, розгляд цієї проблематики має актуальне значення.

Мета дослідження - виявити основні джерела доходів сучасної NBA та обгрунтувати їх.

Виклад основного матеріалу дослідження. У сезоні 2019/2020 дохід NBA становив 8,76 млрд дол, що на $10 \%$ перевищує показник минулого сезону, навіть незважаючи на всесвітню епідеміологічну ситуацію, яка пов'язана з COVID-19 (збиток ліги загалом оцінюються у 350-450 млн дол [15]. Водночас аналітики спортивного ринку зазначають, що збільшення прибутків відбуватиметься й надалі, зокрема передбачають, що наступного сезону на 8 \% збільшаться прибутки від продажу квитків та абонементів на матчі. Фінансові потоки в NBA не вичерпуються, і володіння клубом стає забавою, яка, окрім того, є досить прибутковою [1]. Перш за все це відбувається тому, що клуби дорожчають. Зокрема, Forbes [8] оцінює кожну франшизу NBA в суму не менше 1 млрд доларів, а середня вартість франшизи NBA втричі вища, ніж 5 років тому, і у 2020 році становить близько 2,12 млрд дол. До прикладу, у 2018 році засновник Alibaba Джозеф Цай домовився впродовж трьох років викупити Brooklyn Nets за 2,35 млрд дол, а пізніше, у 2019-му, додав до договору ще й арену «Barclays Center» у Брукліні. Загальна сума договору становила 3,3 млрд дол. Водночас найдорожчою франшизою NBA сьогодні вважається New York Knicks. Її вартість у 2020 році оцінена у 4,6 млрд дол, що на 14 \% вище, ніж у попередньому сезоні. У загальному рейтингу вартості спортивних франшиз New York Knicks поступаються лише одній команді 3 NFL Dallas Cowboys, ціна якої сьогодні - 5,5 млрд дол. На другому місці в середині ліги 3 показником вартості у 4,4 млрд дол - франшиза Los Angeles Lakers. Третьою командою в цьому рейтингу вказано Golden State Warriors, вартість якої було 
оцінено в 4,3 млрд дол. Саме ці три команди мають найвищі прибутки в лізі.

Клуби дорожчають не лише через внутрішні фактори та закони, що діють у середині NBA. Збільшення їхньої вартості пов'язане й із зовнішніми фондовими ринками США, які за останні п'ять років також суттєво зросли. Водночас, згідно iз законодавством США для власників активів спортивних клубів діє 15-річний пільговий період на оплату податків, тому купівля команди $є$ досить вигідним капіталовкладенням ще й з цієї позиції.

Окрім того, що клуби NBA $є$ досить дорогим активом, більшість із них добре заробляє. Середній прибуток клубу NBA у 2017 році становив близько 50 млн доларів, а вже станом на 2019 рік - 70 млн дол. Схема розподілу доходів, яку впровадила ліга в 2011 році, гарантує прибуток кожному клубу, якщо він не розширює свою зарплатну відомість i не влазить у податок на розкіш. Діючи в межах цього правила в останньому сезоні, п’ять команд змогли заробити близько 100 млн дол і лише Oklahoma City Thunder зазналазбитків у 23 млн дол, оскільки заплатила податок вартістю 61 млн дол за надвисокі гонорари для своїх гравців.

Обговорюючи найприбутковіші статті в контексті проведення змагань NBA, варто зазначити, що Асоціація нещодавно підписала нові договори 3 телебаченням, зокрема 3 телекомпаніями ESPN та TNT (до 2025 року), за якими сумарно отримає 24 млрд дол за чотири роки. Уся фінансова стабільність Ліги основана на тому, що доходи будуть, нехай повільно, але збільшуватися. Поки немає потреби працювати над новими ТВ-контрактами, NBA розробляє інші потенційні шляхи прибутків. ESPN має права на 100 ігор регулярного чемпіо- нату, 44 гри, які відбуваються після завершенню сезону й трансляції драфту та драфту-лотереї. 3i свого боку, TNT транслює 67 прайм-тайм ігор протягом регулярного сезону, а також володіє правами на All-Star Weekend. Загальна сума колективного телевізійного контракту, укладеного NBA, розподіляється між 30 командами в рівних частках, незалежно від місця в турнірній таблиці [1].

Окрім того, Асоціація має власний канал на телебаченні - NBA TV, на який встановлена платна підписка. До прикладу, щоб придбати пакет прямих трансляцій на всі ігри команд League pass, доведеться заплатити 70 доларів, а пакет Теат choice на одну команду, зі свого боку, має вартість у 50 доларів. Доходи команди NBA отримують і від укладання угод із місцевими телеканалами, а надходження від них додаються до сумарного доходу. Наприклад, Los Angeles Lakers отримує сьогодні найбільший дохід від контракту з місцевим телебаченням. Контракт укладений із Time Warner Cable на термін 20 років має принести дохід у 4 млрд доларів, це в середньому 200 млн доларів на рік [4].

В Асоціації збільшилися й доходи від продажу прав на телевізійні трансляції матчів: місцевим компаніям - на 70 млн доларів і національним телемережам - на 20 млн доларів. Рекламодавці охоче співпрацюють 3 телеканалами, які транслюють баскетбольні матчі, оскільки спорт - один із небагатьох видів телевізійного контенту, який глядач намагається дивитися в прямому ефірі. Запис гри на YouTube або іншому відеопорталі через кілька днів після матчу переглядає значно менша частина аудиторії.

Реальні доходи NBA від телетрансляцій наведено на рисунку 1.

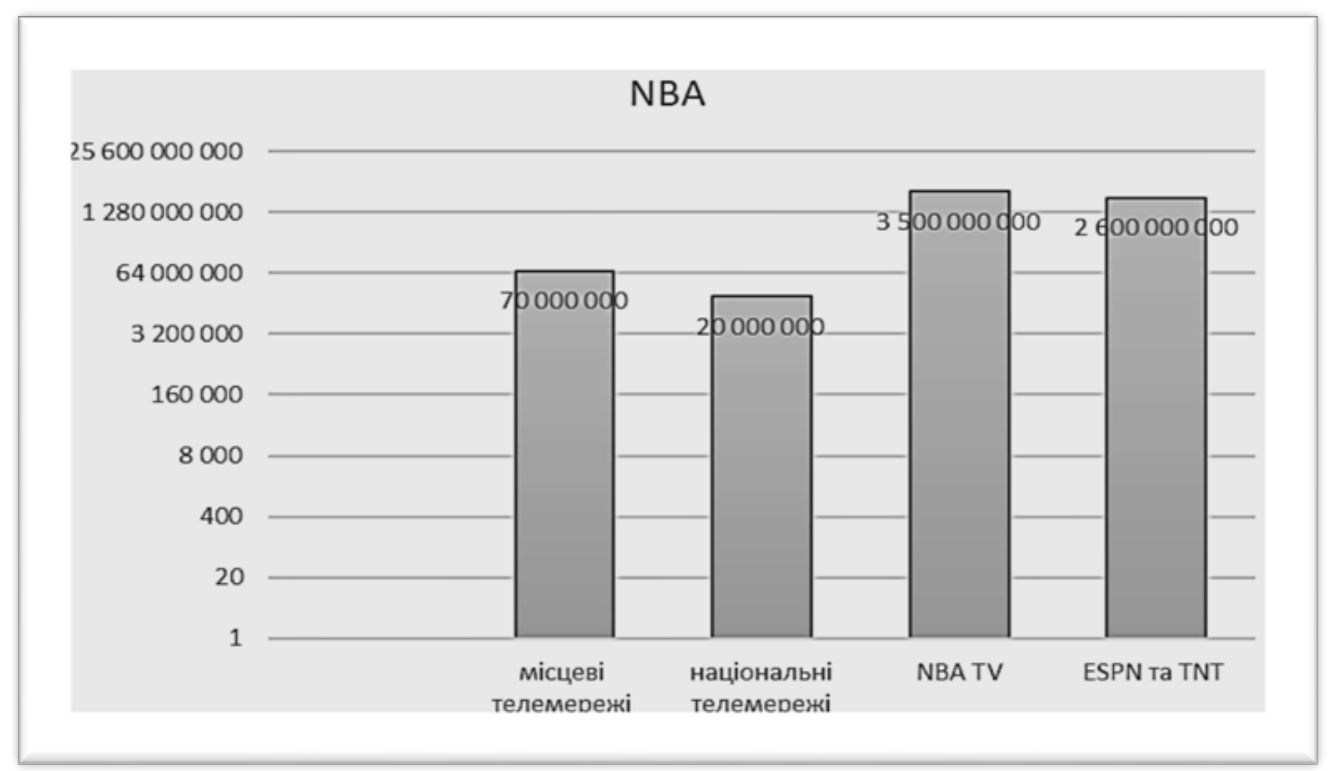

Рис. 1. Доходи від телевізійних контрактів NBA 
Приблизно так само діє і схема розподілу грошей, зароблених NBA на мерчандайзингу - через мережу офіційних магазинів NBA Store. Тому, коли любитель баскетболу купує в офіційному магазині ігрову майку Леброна Джеймса, то гроші, заплачені за неї, дістаються не тільки його клубу «Los Angeles Lakers», але частина їх надходить й іншим клубам.

Нині доходи будь-якого клубу приблизно на $40 \%$ складаються з власних заробітків і на $60 \%$ 3 того, що надходить по лінії NBA [1, с. 13].

Суттєвий заробіток клубам приносить продаж абонементів і квитків, контракти з місцевими медіаспонсорами, а також дохід від експлуатації власних арен, включно з продажем їжі та напоїв під час ігор. Зокрема, на ігри команди Washington Wizards абонемент коштує від 704 доларів, а на ігри Boston Celtics - 2420 доларів, матчі Golden State Warriors обходяться не дешевше ніж 2365 доларів. Щоб купити разовий квиток на гру Los Angeles Lakers - Los Angeles Clippers доведеться заплатити 270 доларів, а на гру Chicago Bulls можна сходити за 25 доларів. Ціни на білети фінальної серії плей-оф на сайтах, які поширюють квитки 3 комісією, досягає 45 тисяч доларів. За таку суму пропонують відразу два квитки в ложу для особливо важливих персон, бо окремо вони не продаються. Ціни на абонементи та квитки є дуже різними, оскільки це залежить від кількості суперзірок у командах. Середня відвідуваність стадіону становить 17809 осіб [4].

Доходи від продажу квитків залежать від наявності «зірок» у тому чи іншому клубі і рівня командної гри клубу. Наприклад, доходи NBA від продажу квитків у сезоні 2014/2015 збільшилися відразу на 100 млн доларів порівняно 3 попереднім сезоном. Це було зумовлено поверненням Леброна Джеймса в Cleveland Cavaliers, що викликало різке збільшення відвідувачів на домашній арені клубу Квік Лоенс (20 тис. місць). А вдалий виступ Atlanta Hawks після довгої перерви повернув публіку на трибуни «Філіпс Арени» (19 тис.). Середня ціна квитка в NBA становила 54 долари.

Бренд «Tissot» став першим офіційним хронометристом NBA, уклавши шестирічний контракт на 200 млн доларів, а телекомунікаційна компанія «Verizon» змінила Sprint, підписавши трирічну угоду на 400 млн доларів. Тепер завдяки такій співпраці та маркетингу всі відео NBA є на мобільному відеосервісі «Verizon» [1].

Щодо студентської асоціації, то вона досі вважається некомерційною організацією і не платить податки до федерального бюджету. Проте доходи NCAA у 2017 році перевищили мільярд доларів, а чистий прибуток був більше ніж 100 млн. Цікавим є факт, що $75 \%$ своїх доходів асоціація, в якій налічується пів сотні видів спорту, отримує від баскетболу. При тому, що ця організація отримує досить великі доходи, спортсмени не мають офіційної заробітної плати й фактично не отримують жодних матеріальних заохочень. Водночас тренери, які в ній працюють, отримують більше, ніж їхні колеги у професійних лігах, що призводить до безлічі конфліктів. Хабарі, ставки, приховування злочинів, порушення правил рекрутингу для школярів, нелегальні виплати спортсменам та їхнім родинам - усе це присутне в NCAA впродовж фактично всієї іiї історії. Цікавим є факт, що в сезоні 2017/2018 до розслідування проблем студентського баскетболу залучили навіть ФБР. Також було опубліковано звіт спеціальної комісії, яку очолює ексдержсекретарка США Кондоліза Райс, у якому, як правило, вся відповідальність перекладається на інших - переважно на взуттєві бренди та NBA. Причиною всіх бід комісія вважає правило, за яким NBA забороняє драфтувати гравців зі школи, і закликає його скасувати [4, с. 7].

Ще у 2005 році попередній комісіонер NBA Девід Стерн закрив драфт для школярів і відправив усіх щонайменше на рік у NCAA, обгрунтовуючи це тим, що баскетбольна молодь як психологічно, так і фізично не готова до серйозних навантажень. Упродовж цього року молоді баскетболісти мали вийти на необхідний рівень підготовленості [11]. Однак це не дало жодного результату. Тобто NCAA не виконує своєї ключової ролі.

NBA розширила свої можливості щодо акомодації молодих гравців. У заявках команд $\epsilon$ два додаткових місця для двосторонніх контрактів, майже в кожного клубу (27 з 30) є своя команда в так званій G-лізі - Лізі розвитку (існує з 2001 року, останній ребрендинг відбувся у 2017 році), яка функціонує аналогічно до самої NBA. Зарплати в ній постійно ростуть, рівень скаутингу шкільного баскетболу також виріс, а NBA готова займатися розвитком молоді. Варто зазначити, що G-ліга уклала контракт iз Twich на онлайн-трансляції матчів, а якщо в лізі гратимуть Зіон Вільямсон, Бол Бол і син Шакіла О'Ніла, то це додасть зацікавленості до фарм-ліг, що, відповідно, може привабити нових спонсорів і дасть змогу підписати нові економічно вигідні контракти. Високий інтерес молодих баскетболістів до G-ліги простежується, до прикладу, і в тому, що Даріуз Бейзлі, один із топгравців драфту 2019-го, оголосив про те, що не вступатиме до університету Сиракьюз чи іншого коледжу, а натомість одразу підписав контракт із G-лігою на сезон 2018/2019 [10; 12].

Крім того, NBA є однією з найпопулярніших ліг у Китаї. Проєкт NBA China почав реалізовуватися ще 10 років тому. Це перш за все було пов'язано з успіхом Яо Міна в Америці. Сьогодні ця частина ліги оцінюється в 4 млрд доларів. За підрахунками NBA, 750 мільйонів китайців 
у сезоні 2016/2017 дивилися іiі ігри. У Китаї в баскетбол грають близько 300 млн осіб. Загалом 144 млн китайців стежили за NBA в соціальних мережах Китаю, на NBA в Weibo підписано вшестеро більше людей, ніж на сторінку ліги в заблокованому в Китаї твітері [1; 2].

Однак у 2019 році NBA стикнулася із серйозним конфліктом у Китаї. Причиною був пост у соціальній мережі Facebook головного менеджера команди Houston Rockets Деріла Mopi, яким він підтримав протести в Гонконзі [6]. Як наслідок, сьогодні Китай фактично відмовляється співпрацювати 3 NBA (усі китайські партнери розірвали зв'язки 3 лігою), телеканали відмовляються транслювати баскетбольні матчі ліги (при тому, що телегігант Китаю Tencent у 2015-му підписав п'ятирічний контракт на 1,5 млрд дол із NBA), а китайці - відвідувати їх. За оцінками експертів, ліга втратить на цьому близько 4 млрд дол за рік.

Окрім китайської території, NBA активно захоплює спортивний ринок і в Африці, Індії, Латинській Америці. С прогнози, що в Мексиці найближчим часом з'явиться нова команда, проте, найімовірніше, спершу в Лізі розвитку.

Щодо інших джерел доходів ліги варто згадати i про спонсорів. Зокрема, із сезону 2018/2019 в NBA вперше з'явилися так звані чужі логотипи на формах. Ключовим сьогодні є логотип «Nike», який $€$ новим екіпірувальником ліги (раніше Adidas міг брендувати тренувальні комплекти й сувенірну продукцію, але не ігрові майки) i на додаток кожен клуб може розмістити логотип власного спонсора (таку угоду клуб може підписати лише на три роки).

Компанія «Nike» перехопила в Adidas контракт на екіпірування команд NBA, угода на вісім років мала б приносити Асоціації понад 1 млрд доларів щорічно (за угодою з Adidas було 400 млн доларів). Проте з'явилася інформація, що вже 3 наступного ігрового сезону логотип «Nike» замінить Jumpman (логотип компанії «Jordan Brand», яка є власністю славнозвісного Майкла Джордана) [3].

Окрім ключового логотипу, iз 30 команд NBA 20 тепер розміщують рекламу власних спонсорів на формах, інші 10 - тільки планують підписати спонсорські контракти [1]. Завдяки цьому контракту фінанси організації збільшилися на 200 млн.

Однак цей проєкт дещо розчарував лігу, оскільки вона очікувала більшого фінансового ефекту. Лише 2/3 клубів розмістили рекламу на своїй формі, відповідно, ліга недозаробила приблизно 50 млн й скоригувала прогноз стелі зарплат на наступний сезон приблизно на 1 млн у бік зменшення. Водночас це 200 млн дол, яких раніше не було. Найбільший контракт у чемпіонів із Golden State Warriors, яким японський гігант Rakuten платить по 20 млн на рік.
Окрім чистої фінансової вигоди від реклами, цей проєкт також відкриває можливості й щодо нових корпоративних партнерських програм, наприклад GE не тільки розміщує логотип на формі «Boston Celtics» (причому перефарбовуючи його в клубні кольори, чого багато хто не робить), а й поставила hi-tech обладнання на нову тренувальну базу «Celtics», яка відкрилася влітку 2019 року. Це вже не просто реклама, а повноцінна співпраця.

Варто зазначити, що NBA першою 3 найбільших північно-американських професійних ліг дозволила розміщувати логотипи спонсорів на формах гравців. До сьогодні NFL, MLB та NHL забороняють подібне, форми їхніх гравців не містять нічого зайвого [5].

Медіааналітики 3 GumGumSports оцінили вигоду компаній від розміщення реклами в 350 млн в одних лише соцмережах (а $є$ ще охоплення потенційних покупців і завдяки телебаченню, сувенірній продукції та рекламі на стадіоні), і найбільше від реклами на формі виграють Goodyear (Cleveland Cavaliers), Rakuten, General Electric, Wish (Los Angeles Lakers) i Squarespace (New York Knicks) [4].

Майки не єдине потенційне джерело збільшення доходів коштом реклами. Ліга давно брендує Матч усіх зірок і конкурси (конкурс данків офіційно зветься Verizon Slamdanck, a конкурс триочкових кидків спонсорує JBL), навіть фармлігу перейменували з D-ліги у G-лігу через те, що титульним спонсором став Gatorade $[1 ; 10 ; 14]$.

Уперше реклама 3'явилася на формі в Матчі всіх зірок NBA 2016-го та 2017 років, тоді титульне розміщення мала KIA. Сума, яку ліга отримала від південнокорейського виробника автомобілів, ніде не розголошується. Проте відомі умови, за яких клубам дали змогу співпрацювати із спонсорами. Тепер $25 \%$ від кожного контракту з розміщення нашивки йдуть у пул розподілу доходів NBA, 50 \% розподіляються між гравцями відповідно до колективного договору, і тільки $25 \%$ отримує клуб. Водночас командам заборонено рекламувати компанії, які пов'язані з азартними іграми, алкоголем або політикою. Майки з логотипом спонсора не можна купити у фаншопі, а лише на арені перед матчем [1].

Першим клубом NBA, що продав рекламне місце на формі, стала Philadelphia 76ers, яка домовилася із сервісом перепродажу квитків «StubHub». Трирічна угода в сумі принесе клубу 15 мільйонів доларів - це по 5 мільйонів на рік. Аналогічну за термінами й сумою угоду уклав Sacramento Kings, спонсором став виробник мигдалю Blue Diamond Growers. Контракт передбачає не тільки нашивки на формі, але й рекламу на стадіоні, а також додавання мигдалю й мигдалевого молока в меню арени. Minnesota Timberwolves підписала контракт iз виробником фітнес-трекерів. Сума угоди варіюється від трьох до восьми мільйонів за рік. Грав- 
цям не можна носити браслети на майданчику, але Fitbit бажає отримувати дані про сон спортсменів, вплив графіку виїзних ігор на результати і взаємодії гравців між собою. Співпраця 3 Minnesota Timberwolves не перший досвід для Fitbit. Раніше вони вже забезпечували софтом Golden State Warriors i Cleveland Cavaliers, а також була інтеграція в NBA2K17. Кожен власник фітнес-браслета, який зробив понад 10 тисяч кроків за день, отримував тимчасове поліпшення навичок для свого віртуального гравця в режимі Мy Player NBA2K17 [1].

У 2016 році об'єдналися два головних символи Milwaukee Bucks: для маскота Milwaukee Bucks на ім'я Банго довелося на кожній домашній грі їздити по паркету на мотоциклі від Harley-Davidson, це відбувалося в тайм-аутах останньої чверті. Логічним продовженням співпраці стало розміщення реклами на формі - контракт коштує від 2,5 до 6 мільйонів доларів на рік [7].

Партнерство може бути не лише чисто комерційним, а й корисним для вболівальників. Toronto Raptors і компанія «Sun Life Financial» прописали в контракті пункт про спільну програму інформування та профілактику діабету. Подібний контракт підписала команда «Utah Jazz» 3 Qualtrics. Компанія відмовилася від розміщення логотипу на майках, замість того з'явиться емблема проєкту «П'ять заради битви», суть якого - мотивувати людей на пожертвування п'яти доларів на дослідження й боротьбу з раком. За перший рік дії контракту вдалося зібрали понад 1 мільйон доларів. За п’ять років творці мають намір зібрати 50 мільйонів доларів. Крім того, на матчах «Юти» показують 30-секундні ролики про дослідження раку. Вартість контракту становить близько 4 мільйонів доларів на рік [1, с. 7].

Рекламною поверхнею може стати навіть паркет: у лютому 2019-го на арені Ворріорс показали тизер до нової частини відеогри God Of
War. Подібна реклама в перервах, на відміну від звичайної, добре видна всім уболівальникам на трибунах і показується глядачам у трансляціях League Pass, заодно не потрапляючи в геообмеження. Винахідливість у доставці реклами до користувача виходить на новий рівень, і нашивка на формі це лише ії частина.

NBA заробляє багато, але все ж таки продовжує шукати все нові джерела доходів. Вона починає захоплювати й кіберспортивний ринок за допомогою NBA2K. Ця ліга $є$ віртуальним аналогом самої NBA. Прогнозується, що вже в близькому майбутньому кіберспортсмени-баскетболісти за один сезон отримуватимуть вищі заробітні плати, аніж баскетболісти в $\mathrm{G}-л і з і$ [1, с. 7].

Однією зі сфер фінансової зацікавленості ліги $\epsilon$ розроблення мобільних додатків. Наприклад, у League Pass незабаром планується запуск можливості «мікроплатежів». Уболівальники зможуть усього за 99 центів переглядати фрагменти найбільш напружених моментів матчу. Сьогодні вже близько половини квитків на ігри продається через мобільний телефон, а трансляції $з$ мобільних пристроїв стають усе більш якісними (від HD до UHD та VR форматів).

Ще одним досягненням NBA $є$ підписання спонсорської угоди 3 компанією «MGM Resorts International» у 2018 році. Наприклад, у США вперше з'являється офіційний спонсор, однією зі сфер діяльності якого є азартні ігри. ESPN стверджує, що між сторонами підписано трирічну угоду, за умовами якої NBA заробить 25 мільйонів доларів. Партнерство дасть змогу MGM використовувати офіційний бренд NBA, а також логотип команд по всій країні. Водночас спонсор зобов' язується просувати канал NBA, сайт та його програму $[1 ; 4]$.

Підсумовуючи, варто звернути увагу на рисунок 2, де, до прикладу, представлено доходи від основних спонсорських контрактів NBA.

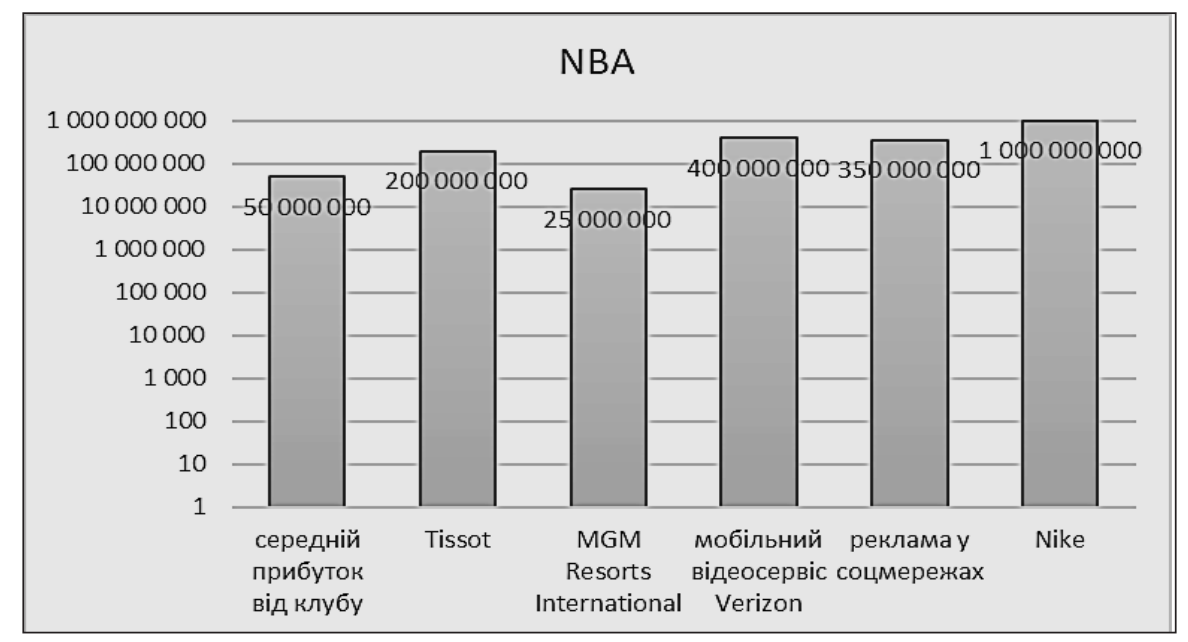

Рис. 2. Доходи від основних спонсорських компаній NBA 
Обговорюючи зарплати гравців як ключових персон, які створюють основний продукт для продажу в лізі - видовище, варто зазначити, що вони безпосередньо пов'язані з фінансовим станом самої NBA. Стеля зарплат формується на основі прогнозу доходів ліги на майбутній сезон - 50 \% доходів йдуть у клуби, а решта 50 \% витрачаються на зарплати баскетболістів. Чим більше заробляє ліга, тим більше отримують спортсмени відповідно [7].

Окрім того, є певні правила, згідно 3 якими формуються всі зарплати в NBA. Мінімальне іiі значення становить 1,5-2,5 млн за сезон залежно від стажу, новачки отримують -815 тисяч. Проте $€$ обмеження: максимальна зарплата становить 25-35 \% від стелі зарплат. У сезоні 2019/2020 межа становить 99 млн дол. [8].

Термін контракту може становити від одного сезону й до п'яти років і в цей період зарплати не переглядаються. Гравець не може вимагати збільшення в середині контракту, але й меншою його зарплата ніяк не може стати. Гравці отримують платою тільки за регулярний сезон. У плей-оф є невеликий бонусний фонд від NBA, приблизно 200 тисяч доларів для чемпіонів. За останні роки доходи ліги значно зросли, а значить і піднялися заплати. Найдорожчий контракт в історії NBA є у Стефана Каррі (Golden State Warriors), який становить 34682550 доларів, друге місце посідає Леброн Джеймс (Cleveland Cavaliers) - 33285 709, а третє місце Пол Міллсеп (Denver Nuggets) - 30769231 [7].

Водночас, повертаючись до світової проблеми 3 пандемією COVID-19, варто зазначити, що внаслідок призупинення ігор NBA, гравцям скоротили заробітні плати на 25 \% починаючи з травня 2020 року. Спираючись на Колективну угоду ліга може не сплачувати баскетболістам 1,08 \% заробітної плати за кожну не зіграну гру внаслідок епідемії чи війни [4]. Станом на тепер ліга відновила сезон, однак у ньому беруть участь лише 22 найкращих команди. Це пов'язано з фінансовою стороною, оскільки якби Ліга скасувала регулярний чемпіонат, то не проведеними були б 293 матчі. У такому разі гравці втратили б майже 645 млн дол. У разі проведення 88 матчів ці втрати становитимуть 300 млн дол. [9].

Тобто сьогодні NBA, будучи однією 3 найзаможніших ліг північно-американського професій- ного спорту, отримує доходи, що вимірюються в мільярдах доларів. Вона укладає все вагоміші в економічному плані контракти 3 телекомпаніями, фірмами тощо. Водночас спостерігається значна конкуренція на ринку за те, щоб бути учасниками великого баскетбольного шоу, що дає змогу NBA суттєво не хвилюватися за своє майбутнє. Водночас $є$ фактори, які все ж мають вплив на зниження планової прибутковості ліги, зокрема в поточному сезоні - це пандемія COVID-19 і конфлікт у Китаї.

Висновки. Сьогодні NBA можна вважати фактично взірцевою лігою з погляду ведення спортивного бізнесу. Її прибутки постійно ззбільшуються, i станом на поточний сезон ліга заробила понад 8 млрд дол. Загалом середній прибуток клубу в лізі, порівнюючи 3 попереднім сезоном, збільшився на 20 млн дол і сьогодні становить 70 млн. Окрім того, п'ять клубів перетнули межу доходу в 100 млн дол.

Ключовими джерелами доходів NBA виступають продажі прав на телетрансляції (контракт 3 ESPN та TNT на 24 млрд дол упродовж чотирьох років), продаж квитків та абонементів на матчі (за винятком сезону 2019-2020, коли регулярний чемпіонат фактично не відбувся внаслідок пандемiї COVID-19), угоди зі спонсорами, розширення діяльності ліги поза межами Північної Америки та захоплення зарубіжних спортивних ринків (Китай, Індія, Африка, країни Свропи та Південної Америки), розвиток сучасних технологій у баскетболі (розроблення мобільних додатків для вболівальників, відеоігор, створення кіберліги NBA2K тощо), ліцензійна діяльність ліги.

NBA має чималу кількість перспектив у напрямі економічного розвитку й надалі, а аї функціонери постійно вдосконалюють наявні компоненти спортивного складника, що, як наслідок, сприяє розширенню зацікавлення баскетболом загалом та, відповідно, залученню все більших фінансових ресурсів у розвиток ліги.

Перспективи подальших розробок. Планується встановити ключові джерела прибутків інших організацій професійного спорту на теренах США та країн Європи й обгрунтувати чинники, які впливають на формування економіки цих організацій в конкретних умовах розвитку того чи іншого суспільства.

\section{ЛIТЕРАТУРА}

1. В НБА никогда не закончатся деньги. URL: https://www.sports.ru/tribuna/blogs/basketblogg/1685127. html (дата звернення: 13.10.2019).

2. Китайская грамота: почему команды НБА дорожают быстрее клубов из других лиг. URL: https://www.forbes.ru/biznes/358313-kitayskaya-gramota-pochemu-komandy-nba-dorozhayut-bystreeklubov-iz-drugih-lig (дата звернення: 10.11.2019).

3. Логотип Jordan Brand появится на альтернативной игровой форме команд HБA. URL: https://ua.tribuna.com/basketball/1087182248.html (дата звернення: 8.08.2020).

4. НБА в сезоне 2019/2020. Материал из Википедии. URL: https://ru.wikipedia.org/wiki/\%D0\%9D\% D0\%91\%D0\%90_\%D0\%B2_\%D1\%81\%D0\%B5\%D0\%B7\%D0\%BE\%D0\%BD\%D0\%B5_2019/2020 (дата звернення: $\overline{1} 2.08 .2020)$. 
5. НБА отказалась от традиций ради спонсоров. СБК. URL: https://www.s-bc.ru/news/nba-otkazalas-ottradicij-radi-sponsorov.html (дата звернення: 18.08.2020).

6. Нічого особистого, просто гроші: НБА прогинається під Китай, а в CША цим незадоволені. URL: https:/ua.112.ua/statji/nichoho-osobystoho-prosto-hroshi-nba-prohynaietsia-pid-kytai-a-v-ssha-tsymnezadovoleni-510804.html (дата звернення: 18.08.2020).

7. Сайт Національної баскетбольної Асоціації. URL: http://nba.com/ (дата звернення: 28.09.2018).

8. Самые дорогие клубы НБА - 2020. Рейтинг Forbes. URL: https://www.forbes.ru/biznes/392965samye-dorogie-kluby-nba-2020-reyting-forbes (дата звернення: 01.08.2020).

9. Що ми знаємо і не знаємо про рестарт сезону в НБА. UА футбол. URL: https://www.ua-football.com/ ua/sport/basketball/1591609103-scho-mi-znayemo-i-ne-znayemo-pro-restart-sezonu-v-nba.html. (дата звернення: 15.08.2020).

10. D-League lowers the age requirement to 18 . URL: https://www.espn.com/nba/news/story?id=2407522 (дата звернення: 20.11.2019).

11. Frank P.J. The National Basketball Association: Business, Organization and Strategy. World Scientific. 2011. $75 \mathrm{p}$.

12. Kevin Owens. Future of the NBA and the NBA D-League Going Forward. URL: https://philly.sbnation. com/2011/7/25/2292905/future-of-the-nba-and-the-nba-d-league-going-forward (дата звернення: 15.11. 2019).

13. Kirchberg C. Hoop lore: a history of the National Basketball Association. McFarland. 2007. 110 p.

14. NBA D-League Frequently Asked Questions. URL: https://gleague.nba.com/about/ (дата звернення: 15.11.2019).

15. Potential loss of revenue in the NBA due to the coronavirus (COVID-19) pandemic as of March 2020. URL: https://www.statista.com/statistics/1104004/coronavirus-revenue-loss-nba/ (дата звернення: 6.08.2020).

\section{REFERENCES}

1. V NBA nikogda ne zakonchatsya dengi [The NBA will never run out of money]. Retrieved from https://www.sports.ru/tribuna/blogs/basketblogg/1685127.html.

2. Kitayskaya gramota: pochemu komandy NBA dorozhayut bystree klubov iz drugikh lig. [Chinese literacy: why NBA teams are getting more expensive faster than clubs from other leagues]. Retrieved from https://www.forbes. ru/biznes/358313-kitayskaya-gramota-pochemu-komandy-nba-dorozhayut-bystree-klubov-iz-drugih-lig.

3. Logotip Jordan Brand poyavitsya na alternativnoy igrovoy forme komand NBA [Jordan Brand logo will appear on an alternative game form of NBA teams]. Retrieved from https://ua.tribuna.com/basketball/1087182248.html.

4. NBA v sezone 2019/2020. Material iz Vikipedii [NBA in the 2019/2020 season. Material from Wikipedia]. Retrieved from https://ru.wikipedia.org/wiki/\%D0\%9D\%D0\%91\%D0\%90_\%D0\%B2_\%D1\%81\%D0\% B5\%D0\%B7\%D0\%BE\%D0\%BD\%D0\%B5 2019/2020.

5. NBA otkazalas ot traditsiy radi sponsorov. SBK [NBA refused traditions for sponsors. SBK]. Retrieved from https://www.s-bc.ru/news/nba-otkazalas-ot-tradicij-radi-sponsorov.html.

6. Nichogo osobystogo, prosto groshi: NBA progynayetsya pid Kytay, a v SShA tsym nezadovoleni [Nothing personal, just money: the NBA is bending over China, and the United States is dissatisfied with it]. Retrieved from https://ua.112.ua/statji/nichoho-osobystoho-prosto-hroshi-nba-prohynaietsia-pid-kytai-a-v-ssha-tsym-nezadovoleni-510804.html.

7. Sayt Natsionalnoyi basketbolnoyi Asotsiatsiyi [Website of the National Basketball Association]. Retrieved from http://nba.com.

8. Samye dorogye kluby NBA - 2020. Reytyng Forbes [The most expensive clubs in the NBA - 2020. Forbes rating]. Retrieved from https://www.forbes.ru/biznes/392965-samye-dorogie-kluby-nba-2020reyting-forbes.

9. Shcho my znayemo i ne znayemo pro restart sezonu v NBA. UA futbol [What we know and do not know about the restart of the season in the NBA. UA football]. Retrieved from https://www.ua-football.com/ua/ sport/basketball/1591609103-scho-mi-znayemo-i-ne-znayemo-pro-restart-sezonu-v-nba.html.

10. D-League lowers the age requirement to 18 . Retrieved from https://www.espn.com/nba/news/story?id=2407522.

11. Frank P.J. (2011) The National Basketball Association: Business, Organization and Strategy. World Scientific. $2011.75 \mathrm{p}$.

12. Kevin Owens. Future of the NBA and the NBA D-League Going Forward. Retrieved from https://philly. sbnation.com/2011/7/25/2292905/future-of-the-nba-and-the-nba-d-league-going-forward (date of request: 15.11. 2019).

13. Kirchberg C. (2007) Hoop lore: a history of the National Basketball Association. McFarland. 2007. 110 p.

14. NBA D-League Frequently Asked Questions. Retrieved from https://gleague.nba.com/about.

15. Potential loss of revenue in the NBA due to the coronavirus (COVID-19) pandemic as of March 2020. Retrieved from https://www.statista.com/statistics/1104004/coronavirus-revenue-loss-nba. 


\section{ВИМОГИ ДО ОФОРМЛЕННЯ СТАТЕЙ У ЗБІРНИКУ НАУКОВИХ ПРАЦЬ «ВІСНИК ЗАПОРІЗЬКОГО НАЦІОНАЛЬНОГО УНІВЕРСИТЕТУ. ФІЗИЧНЕ ВИХОВАННЯ ТА СПОРТ»}

\section{Вимоги до оформлення статей:}

До друку приймаються статті, що мають наукову і практичну цінність. Автор має право представити тільки одну наукову статтю в один номер, яка раніше не публікувалася. Автор несе відповідальність за оригінальність тексту статті, точність наведених фактів, цитат, статистичних даних, власних назв, географічних назв та інших відомостей, а також за те, що в матеріалах не містяться дані, що не підлягають відкритій публікації. Редакція не несе відповідальності за викладену в статті інформацію. Остаточне рішення про публікацію ухвалюється редакцією, яка також залишає за собою право на додаткове рецензування, редагування і відхилення статей.

\section{Технічні вимоги:}

- до друку приймаються статті українською, російською та англійською мовами;

- електронний варіант статті у форматі *.doc, *.docx або *.rtf, підготовлений у текстовому редакторі Microsoft Word;

- формат A4 через 1,5 інтервал;

- шрифт Times New Roman, розмір 14;

- поля: ліве -3 см, праве $-1,5$ см, верхнє, нижнє -2 см.

\section{Структура статті:}

рядок 1 - УДК (вирівнювання по лівому краю);

рядок 2 - назва тематичного розділу (вирівнювання по лівому краю);

рядок 3 - назва статті (вирівнювання по центру, напівжирний шрифт, великі літери);

рядок 4 - прізвище та ініціали автора статті; науковий ступінь, вчене звання, посада із зазначенням кафедри (вирівнювання по центру);

рядок 5 - місце роботи (навчання), адреса роботи (навчання), orcid-код, електронна адреса автора (вирівнювання по центру).

Якщо автор не має orcid-коду, його можна отримати за посиланням https://orcid.org/

абзац 1 - розширена анотація (1800 знаків без пробілів) та ключові слова (мінімум 5 слів), написані мовою, як і уся стаття;

абзац 2 - назва статті (напівжирний шрифт, усі літери великі), прізвище, ініціали автора, науковий ступінь, вчене звання, посада із зазначенням кафедри, місце роботи (навчання), адреса роботи (навчання), orcid-код, електронна адреса автора, розширена анотація (1800 знаків без пробілів) та ключові слова (мінімум 5 слів), написані англійською мовою. Переклад англійською мовою повинен бути достовірним (не машинним).

У випадку, якщо стаття не українською мовою, обов'язково подаються назва статті (напівжирний шрифт, усі літери великі), прізвище, ініціали автора, науковий ступінь, вчене звання, посада із зазначенням кафедри, місце роботи (навчання), адреса роботи (навчання), orcid-код, електронна адреса автора, розширена анотація (1800 знаків без пробілів) та ключові слова (мінімум 5 слів), написані українською мовою.

\section{Структурні елементи основного тексту статті:}

Постановка проблеми (постановка проблеми у загальному вигляді та ії зв'язок із важливими науковими чи практичними завданнями; аналіз останніх досліджень і публікацій, де вказати започаткування розв'язання даної проблеми та на які опирається автор, а також обов'язково виділення невирішених раніше частин загальної проблеми, яким присвячена стаття).

Мета статті (висловлюється головна ідея даної публікації, яка суттєво відрізняється від сучасних уявлень про проблему, доповнює або поглиблює вже відомі підходи; звертається увага на введення до наукового обігу нових фактів, висновків, рекомендацій, закономірностей або уточнення відомих раніше, але недостатньо вивчених).

Виклад основного матеріалу дослідження з обгрунтуванням отриманих наукових результатів.

Висновки і перспективи подальших розробок у цьому напрямку.

Література розміщується після статті у порядку згадування; друкується через 1,5 інтервал, 14 розміром, шрифтом Times New Roman i оформляється у відповідності вимог міждержавного стандарту ДСТУ 8302:2015. 
Посилання на літературу в тексті слід давати в квадратних дужках, наприклад, [2, с. 25; 5, с. 33], в яких перша цифра вказує порядковий номер джерела в списку літератури, а друга - відповідну сторінку в цьому джерелі; одне джерело (без сторінок) відокремлюється від іншого крапкою $з$ комою $[3 ; 4 ; 6 ; 8 ; 12 ; 15]$.

Наприкінці статті розміщується транслітерована і перекладена англійською версія літератури (References), оформлена згідно з вимогами АРА (American Psychological Association).

Порядок подання матеріалів:

Для публікації статті у фаховому науковому виданні необхідно надіслати на електронну адресу редакціï editor@sport.journalsofznu.zp.uа наступні матеріали:

добре вичитану наукову статтю, обов'язково оформлену відповідно до вказаних вимог;

інформаційну довідку про автора;

відскановане підтвердження сплати коштів (реквізити для сплати надаються автору після вдалого проходження рецензування).

Зразок оформлення назви електронних файлів: Іванов_I.І._стаття, Іванов_I.I._оплата.

Адреса та контактні дані:

Редакція збірника наукових праць «Вісник Запорізького національного університету. Фізичне виховання та спорт»,

вул. Дніпровська, 33А, корп. 4, ауд. 217, Запоріжжя, Україна, 69063

Телефон: +380665357687

Електронна пошта: editor@sport.journalsofznu.zp.ua

Офіційний сайт: www.journalsofznu.zp.ua/index.php/sport 